\title{
Assessment of Traffic Safety Performance of School Buses in UAE
}

\author{
Nada B. Al Naser and Yaser E. Hawas
}

\begin{abstract}
This paper discusses the adopted methodology to assess the traffic safety performance measures of the school buses in the UAE. It describes the process of designing two types of surveys, sampling, and analysis of the results using descriptive statistical analysis. The first users' survey is designed to determine the degree of implementation of the applied performance measures in school buses from the users' viewpoint. The target groups of the second survey are the school administrators. In this survey, the records of the traffic accident that school buses had been involved in, in the last five years, were collected. The study covers many regions in the country. Both surveys were distributed between public and private schools that cover different educational levels (Kindergarten, Primary schools, Preparatory schools, and High schools). The traffic safety performance was particularly assessed using three distinctive performance measures; the rate per bus, the rate per bus user, and the rate per student. The performance measures were compared with the counter measures in USA and Canada.

The paper provides a summary of the findings and outcomes. In addition, a list of recommendations is suggested to improve the traffic safety performance of the school buses in the UAE.
\end{abstract}

Index Terms-School bus, traffic accident, safety performance.

\section{INTRODUCTION}

School bus transport is one of the transportation modes, which is widely used to carry the pupils from their houses to the school and vice versa. The first school bus was introduced in 1827 in north east of London (UK), and was designed to carry 25 children [1]. School bus is defined as a type of bus designed, manufactured and used for student transport: carrying children and teenagers to and from school and school events. It is used to transport students to and from school during school hours, or school-related curricular or extracurricular activities [2]. The National Center for Statistics and Analysis-NHTSA- U.S. Department of Transportation define the school bus related crashes as "Any crash in which a vehicle, regardless of body design, used as a school bus is directly or indirectly involved, such as a crash involving school children alighting from a vehicle" [3].

The percentage of the pupils using the school buses in different countries of the world is sufficient to carry out studies that addresses and measure the traffic safety of these buses, and then suggest recommendations, if needed, to

Manuscript received February 28, 2012; revised March 28, 2012

N. B. Al Naser is with the Roadway Transportation and Traffic Safety Research Center (RTTSRC), Faculty of Engineering at United Arab Emirates University, Al Ain, UAE (e-mail: Nada_AlNaser@uaeu.ac.ae).

Y. E. Hawas was with University of Texas at Austin as a research associate between 1995 till 1998. He is now with Civil and Environmental Engineering Department, Faculty of Engineering at United Arab Emirates University, Al Ain, UAE (e-mail: y.hawas@uaeu.ac.ae). improve the performance and safety of the school buses. The American School Bus Council reported that over half of the country's student population is transported by school bus [4].

Several studies were conducted to quantify the safety measures of school buses. In one study, school bus crashes in the state of Iowa were analyzed for four years (2002-2005). The study concluded that the school buses experience low crash rates, and that the majority of crashes do not lead to injury. It also concluded that the school bus crash fatality and injury rates were 3.5 and 5.4 times, lower than overall all vehicle crash fatality and injury rates, respectively [5]. Another study showed using a school bus is 7 times safer than in the family car, 31 times safer than walking and 228 times safer than riding a bike [6].

Other studies in the literature are more oriented to drivers' responsibility and emphasizing the role of the drivers in enhancing the school bus safety measures. School bus drivers are responsible for the safety and well-being of their passengers, including discipline. They have also more responsibility for the safety of students outside the bus itself as pedestrians [7]. The legal responsibility of the school bus drivers may vary from one state to another [7].

Of particular importance also are the studies that provide comparative assessment of safety measures among various countries. The school bus-related safety in New Zealand was thoroughly examined in [8]. The study provided comparisons between the New-Zealand bus-related safety measures and those of Australia, Canada, USA and UK. The study concluded that the traffic safety concerns tend to be similar to some extent, suggesting the need for vehicle-based measures (e.g. safety belts in school buses) and more safety education [8].

The main objective of this study is to measure the traffic safety performance of the school buses in UAE. This is done mainly by following two complementary methods: 1) Measuring the traffic safety performance of the school buses, primarily through the assessment of the accident records, and 2) Measuring the performance of the school bus service, primarily through a user survey. The following section discusses the details of the methodology used in this study.

\section{Methodology}

The methodology used in this study entails the distribution of two different types of surveys among the users and the school administrators in different regions of the country. Beside, an extensive review of previous relevant studies was carried out for comparative assessment and to identify state-of-practice to improve the safety performance measures of the school buses in different countries. More details are 
described below.

\section{A. Survey Types}

Two different types of surveys were designed to determine; the used/applied performance measures by the various schools in the UAE, the extent to which such measures are implemented and routinely assessed, and the availability and adequacy of the accident records of the school buses (over a period of five years). The two surveys are as follows:

1) User Survey: The target group for this survey is students using the school buses. This survey is intended to assess the opinions of the bus users on the general service [and not limited to safety aspects]. For example, some questions are designed to assess the comfort levels, the bus schedule, in addition to the questions to tackle the bus safety aspects. Namely, the survey questions entail aspects of seating quality, behaviour of the bus driver and supervisor, following the time schedule, crowdness of the bus, supervisor presence, and the safety-related training or the educational lectures provided to bus users.

Moreover, an open-ended question is also included to capture the users' comments and suggestions to improve the service performance.

2) School Administration Survey: The target group for this survey is the schools' administrators. In this survey, some statistical information are collected and recorded to be used for estimating the accident rates [for the last five years]. The statistical information include; the number of accidents which the school buses had been involved in, the number of fatalities and injuries resulted from the accidents, the number of buses, the annual travelled distance in kilometers, the number of students enrolled for using the school bus service, and the total number of students enrolled in the school.

Such information is required to estimate the safety performance measures used in this study, namely; the accident rates, the fatality rates, and injury rates. These rates are represented in three different forms; rates per 10 school buses, rates per 1000 enrolled students, and rates per 1000 students enrolled for using school bus.

\section{B. Survey Distribution}

This study covered many different cities/regions of the UAE. Both surveys were distributed between public and private schools that cover different educational levels (Kindergarten, Primary schools, Preparatory schools, and High schools).

\section{Surveys Sample Size}

According to the statistics form the Ministry of Education and the various educational zones data for the academic year 2009/2010 [9], [10], [11], the total number of enrolled students in all the UAE schools was around 643,000 distributed among 1190 schools.

The minimum sample size required for a $99 \%$ confidence level, and a 5\% confidence interval is: [12]

- Minimum sample size of schools: Accounting for the 1190 schools in the UAE, the minimum sample is estimated to be 427 .

- Minimum sample size of bus users: Accounting for the 643,000 enrolled students in the UAE schools, the minimum sample is estimated to be 665 .
Accounting for the possibility that some schools may not have good records of bus accident records or insufficient information, the targeted sample sizes were set higher than the estimated minimum sample size. The exact collected sample sizes were as follows

- 757 school administrators' surveys, and

- 818 bus users' surveys.

This will result in higher confidence level and/or lesser confidence interval.

\section{RESULTS AND ANALYSIS}

Following the collection of the data in accordance to the survey sample size as indicated earlier, the analysis was carried out. The data were aggregated to represent the UAE as a whole. Results obtained from the surveys analysis are summarized in this part of the paper.

The school surveys included the list of required data and statistics required for the study. The list included the number of school bus accidents, the number of fatalities, the number of injuries, the number of students using the school bus, and the total number of students enrolled in the school. Table I shows these data for the last five academic years (2004-2009), which is then used to determine three different rates; the accident rates, the injury rates, and the fatality rates. These rates are presented and analyzed in parts $\mathrm{A}, \mathrm{B}$, and $\mathrm{C}$ (Tables II, III, and IV) below.

The results in Table I (third row) indicate that the accident rates (per school) are increasing in the past five years. This may be due to the higher student enrollment for using school buses (per school), and the tendency of the schools to provide better school bus service by allowing lesser number of students in the school buses [decreased from 86 in 2004/2005 to 61 in 2008/2009]. This results in higher number of buses per school (as indicated in the last row) and as such higher likelihood of accidents.

The bus users' survey analysis was conducted using the Statistical Program for Social Sciences (SPSS) software. The results of the users' survey analysis are presented in Table VII, and discussed in part $\mathrm{E}$ of this paper.

\section{A. Accident Rates}

Using the collected data and statistics of the school buses, the traffic accidents rates were calculated using three different measures; rates per 10 school buses, rates per 1000 students using buses, and rates per 1000 students enrolled in school. This will allow for comparative analysis with similar measures in other countries. In general, the results indicate that the traffic accident rates are slightly increasing during the last five years. However, the traffic accident rates per 10 buses are slightly decreasing in the last two years. Detailed results are shown in Table II.

TABLE I: STATISTICS AND DATA COLLECTED From SCHOOLS' SURVEY

\begin{tabular}{lccccc}
\hline \multirow{2}{*}{$\begin{array}{l}\text { Data } \\
\text { collected }\end{array}$} & $2004 /$ & $2005 /$ & $2006 /$ & $2007 /$ & $2008 /$ \\
\cline { 2 - 6 } & 2005 & 2006 & 2007 & 2008 & 2009 \\
\hline $\begin{array}{l}\text { Number of } \\
\text { Schools }\end{array}$ & 795 & 791 & 779 & 767 & 757
\end{tabular}




\begin{tabular}{llllll}
$\begin{array}{l}\text { Number of } \\
\text { school-bus } \\
\text { accidents }\end{array}$ & 694 & 617 & 748 & 887 & 908 \\
$\begin{array}{l}\text { Accidents } \\
\text { rate per } \\
\text { school }\end{array}$ & 0.87 & 0.78 & 0.96 & 1.16 & 1.20 \\
$\begin{array}{l}\text { Accident/ } \\
\text { school) }\end{array}$ & & & & & \\
$\begin{array}{l}\text { Number of } \\
\text { fatalities }\end{array}$ & 3 & 1 & 2 & 2 & 1 \\
$\begin{array}{l}\text { Number of } \\
\text { injuries }\end{array}$ & 12 & 4 & 15 & 6 & 18 \\
$\begin{array}{l}\text { Number of } \\
\text { school buses } \\
\text { in service }\end{array}$ & 2691 & 2941 & 3076 & 3468 & 3835 \\
$\begin{array}{l}\text { Number of } \\
\text { students using } \\
\text { the school } \\
\text { buses }\end{array}$ & 231513 & 231891 & 229391 & 232078 & 233504 \\
$\begin{array}{l}\text { Total number } \\
\text { of students } \\
\text { enrolled in } \\
\text { the selected } \\
\text { schools }\end{array}$ & 337091 & 332236 & 328740 & 329099 & 332125 \\
$\begin{array}{l}\text { Average } \\
\text { number of } \\
\text { students in } \\
\text { school } \\
\text { Average } \\
\text { number of } \\
\text { students per } \\
\text { bus * }\end{array}$ & 424 & 420 & 422 & 429 & 439 \\
$\begin{array}{l}\text { Average } \\
\text { number of } \\
\text { buses per } \\
\text { school }\end{array}$ & 3.38 & 3.72 & 3.95 & 4.52 & 5.07 \\
\hline
\end{tabular}

* Numbers of students in the buses is relatively high, because there are two shifts in the day. Buses do two trips are in each day to pick up students (morning and afternoon)

TABLE II: TRAFFiC ACCIDENT RATES OF THE SCHOOL BUSES FoR THE LAST FIVE YEARS

\begin{tabular}{lccccc}
\hline \hline Traffic & \multicolumn{5}{c}{ Academic Year } \\
\cline { 2 - 6 } Accident & $2004 /$ & $2005 /$ & $2006 /$ & $2007 /$ & $2008 /$ \\
Rates Per & 2005 & 2006 & 2007 & 2008 & 2009 \\
\hline $\begin{array}{l}10 \text { school } \\
\text { buses }\end{array}$ & 2.58 & 2.10 & 2.43 & 2.56 & 2.37 \\
$\begin{array}{l}1000 \text { school } \\
\text { bus users } \\
\text { (students) }\end{array}$ & 3.00 & 2.66 & 3.26 & 3.82 & 3.89 \\
1000 students & 2.06 & 1.86 & 2.28 & 2.70 & 2.73 \\
\hline \hline
\end{tabular}

\section{B. Injuries Rates}

Injuries resulted from the school bus accidents were used to estimate the rates of injuries for the last five years. The rates are estimated per 10 school buses, per 1000 school bus users, and per 1000 students enrolled in school. The detailed results are shown in Table III below. The results show that injuries rates fluctuate through the last five years. The least rates were recorded in the academic year 2005/2006, while maximum injuries rates were recorded in both academic years (2006/2007 and 2008/2009).
TABLE III: INJURIES RATES FOR THE LAST FIVE YEARS

\begin{tabular}{|c|c|c|c|c|c|}
\hline \multirow{2}{*}{$\begin{array}{l}\text { Injuries Rates } \\
\text { Per }\end{array}$} & \multicolumn{5}{|c|}{ Academic Year } \\
\hline & $\begin{array}{l}2004 / \\
2005\end{array}$ & $\begin{array}{l}2005 / \\
2006\end{array}$ & $\begin{array}{l}2006 / \\
2007\end{array}$ & $\begin{array}{l}2007 / \\
2008\end{array}$ & $\begin{array}{l}2008 / \\
2009\end{array}$ \\
\hline $\begin{array}{l}10 \text { school } \\
\text { buses }\end{array}$ & 0.04 & 0.01 & 0.05 & 0.02 & 0.05 \\
\hline $\begin{array}{l}1000 \text { school } \\
\text { bus users } \\
\text { (students) }\end{array}$ & 0.05 & 0.02 & 0.07 & 0.03 & 0.08 \\
\hline 1000 students & 0.04 & 0.01 & 0.05 & 0.02 & 0.05 \\
\hline
\end{tabular}

\section{Fatalities Rates}

Using given data in Table I, fatality rates were calculated and recorded in Table IV. In general, the fatality rates exhibit a decreasing trend over the past five years. The maximum fatality rates were recorded in the academic year 2004/2005, while the minimum rates were recorded in both academic years 2005/2006 and 2008/2009.

TABLE IV: FATALITIES RATES FOR THE LAST FIVE YEARS

\begin{tabular}{|c|c|c|c|c|c|}
\hline \multirow{2}{*}{$\begin{array}{l}\text { Fatalities } \\
\text { Rates Per }\end{array}$} & \multicolumn{5}{|c|}{ Academic Year } \\
\hline & $\begin{array}{l}2004 / \\
2005\end{array}$ & $\begin{array}{l}2005 / \\
2006\end{array}$ & $\begin{array}{l}2006 / \\
2007\end{array}$ & $\begin{array}{l}2007 / \\
2008\end{array}$ & $\begin{array}{l}2008 / \\
2009\end{array}$ \\
\hline $\begin{array}{l}10 \text { school } \\
\text { buses }\end{array}$ & 0.011 & 0.003 & 0.007 & 0.006 & 0.003 \\
\hline $\begin{array}{l}1000 \text { school } \\
\text { bus users } \\
\text { (students) }\end{array}$ & 0.013 & 0.004 & 0.009 & 0.009 & 0.004 \\
\hline 1000 students & 0.009 & 0.003 & 0.006 & 0.006 & 0.003 \\
\hline
\end{tabular}

\section{Comparative Analysis of UAE and Other Countries} Rates

An extensive search was conducted to collect school bus related information in similar developed countries. The targeted information included the number of injuries and fatalities resulted from school bus accidents, number of school buses, number of students who are using the school buses, total number of students for the last five years. The aim is to allow fair assessment of the school bus safety measures in the UAE as compared to other countries.

The countries, which are selected to collect the data from, are USA, and Canada. Such countries provide more or less similar student bus services to the ones offered in the UAE. The injury and fatality rates in such countries are calculated and used in the comparison.

In addition, the school bus accident data were collected and used in estimating the accident rates. Nonetheless, the school bus accident rates were not included in the comparison. The reason is that the definition of the school bus accident is somehow variant from one agency (or country) to another. In the UAE, all the accidents are recorded; those involving injuries and no injuries. Even the slightest accidents resulting in minor damage to the vehicle itself are recorded. In general, in the UAE, "all the accidents entailing an accident police report are recorded whether they lead to injury or not". Such definition of accident is not universally adopted, and as such, the definition and subsequently the number of recorded accidents varies from one country to 
another. In the USA, the tendency is to record only the accidents resulting in injuries or fatalities [3]. Furthermore, in the USA the school bus related accident is defined as "A school transportation-related crash is a crash which involves, either directly or indirectly, a school bus body vehicle, or a non-school bus functioning as a school bus, transporting children to or from school or school-related activities" [3]. This definition includes all vehicles used to carry the students; not restricted to the "buses". Due to these differences in definitions, the comparison here is limited to the injury and fatality rates, excluding the accident rates.

Table $\mathrm{V}$ shows the rates of injuries resulted from the school bus traffic accidents, for USA, Canada, and the UAE. Table VI shows the rates of fatalities, resulted from the school bus traffic accidents, for USA, Canada, and the UAE. Results indicate that the annual average injury rates are much lower in the UAE than the other countries (Table V), while the annual average fatality rates are a little higher but close to other rates (Table VI).

TABLE V: * COMPARISON OF ANNUAL AVERAGE INJURIES RATES (UAE AND OTHER COUNTRIES)

\begin{tabular}{llll}
\hline \hline \multirow{2}{*}{$\begin{array}{l}\text { Annual Average } \\
\text { Injuries Rates per }\end{array}$} & USA $^{[13-18]}$ & $\begin{array}{l}\text { Canada } \\
{[19-22]}\end{array}$ & UAE \\
\cline { 2 - 4 } & 0.293 & 0.343 & 0.034 \\
\hline $\begin{array}{l}10 \text { school buses } \\
1000 \text { school bus users } \\
\text { (students) }\end{array}$ & 0.538 & 0.389 & 0.047 \\
1000 students & $\begin{array}{l}\text { Not } \\
\text { Available }\end{array}$ & 0.171 & 0.033 \\
\hline \hline
\end{tabular}

* Presented data have been estimated based on information extracted from the cited references

TABLE VI: * COMPARISON OF ANNUAL AVERAgE FATALITIES RATES (UAE AND OTHER COUNTRIES)

\begin{tabular}{llll}
\hline \hline \multirow{2}{*}{$\begin{array}{l}\text { Annual Average } \\
\text { Fatalities Rates per }\end{array}$} & \multicolumn{3}{c}{ Country } \\
\cline { 2 - 4 } & USA $^{[13-18]}$ & $\begin{array}{l}\text { Canada } \\
{[19-22]}\end{array}$ & UAE \\
\hline 10 school buses & 0.003 & 0.006 & 0.006 \\
$\begin{array}{l}1000 \text { school bus users } \\
\text { (students) }\end{array}$ & 0.005 & 0.006 & 0.008 \\
1000 students & $\begin{array}{l}\text { Not } \\
\text { Available }\end{array}$ & 0.002 & 0.005 \\
\hline \hline
\end{tabular}

* Presented data have been estimated based on information extracted from the cited references

\section{E. Performance Measures (User Survey)}

A total of 818 users' surveys have been distributed and collected from the students using the school buses. The data is then grouped and analyzed using the Statistical Program for Social Sciences (SPSS) software. The average years of using the school buses by the students are around 5 years.

The users' survey addressed questions related to the degree of performance; five levels of performance are specified (very good, good, moderate, bad, and very bad).

Table VII illustrates the distribution of the answers. According to the overall analysis of the users' opinions about the school bus service (Fig.1), as well as, the presented results in Table VII, we can say that, the overall bus service provided for the students is "Good".

TABLE VII: School Bus USERS’ OBSERVATIONS ABOUT THE SERVICE

\begin{tabular}{|c|c|}
\hline Service Observations & ategories \\
\hline Quality of seats & $\begin{array}{ll}\text { - } & \text { Very Good: } 32 \% \\
\text { - } & \text { Good: } 37 \% \\
\text { - } & \text { Moderate: } 22 \% \\
\text { - } & \text { Bad: } 6 \% \\
\text { - } & \text { Very Bad: } 3 \%\end{array}$ \\
\hline $\begin{array}{l}\text { Behaviour of the bus driver and } \\
\text { supervisor }\end{array}$ & $\begin{array}{ll}\text { - } & \text { Very Good: } 59 \% \\
\text { - } & \text { Good: } 30 \% \\
\text { - } & \text { Moderate: } 8 \% \\
\text { - } & \text { Bad: } 2 \% \\
\text { - } & \text { Very Bad: } 1 \%\end{array}$ \\
\hline Following the time schedule & $\begin{array}{ll}\text { - } & \text { Very Good: } 45 \% \\
\text { - } & \text { Good: } 33 \% \\
\text { - } & \text { Moderate: } 16 \% \\
\text { - } & \text { Bad: } 3 \% \\
\text { - } & \text { Very Bad: } 3 \%\end{array}$ \\
\hline Bus is crowded & $\begin{array}{l}\text { - } \quad \text { Yes: } 31 \% \\
\text { - } \quad \text { No: } 69 \%\end{array}$ \\
\hline Presence of supervisor & $\begin{array}{l}\text { - } \quad \text { Yes: } 81 \% \\
\text { - } \quad \text { No: } 19 \%\end{array}$ \\
\hline $\begin{array}{l}\text { Training or lectures on how to use school } \\
\text { bus }\end{array}$ & $\begin{array}{ll}\text { - } & \text { Yes: } 56 \% \\
\text { - } & \text { No: } 44 \%\end{array}$ \\
\hline
\end{tabular}

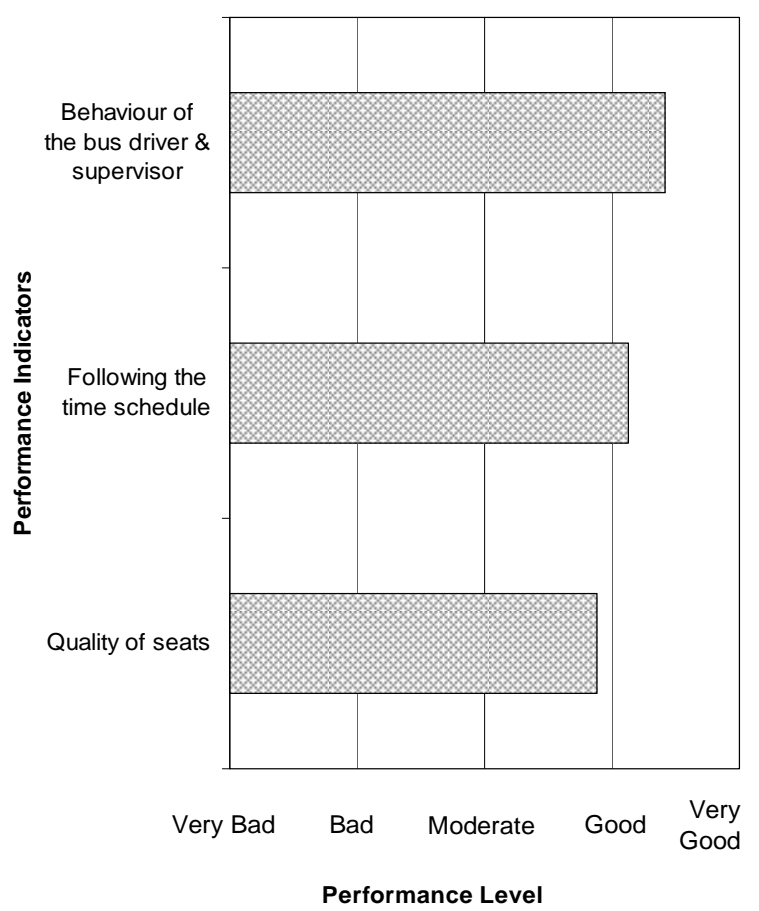

Fig. 1. Overall performance of the school bus services in UAE based on users' opinion.

The most common suggestions to enhance the safety related aspects were:

- Improve the seating: more distance between seats;

- Provide seat belts in the school buses;

- Provide training courses for supervisors on school bus traffic safety; and

- Provide more classes and lectures for the students on traffic safety of the school buses; 


\section{CONCLUSIONS AND RECOMMENDATIONS}

In this study, the traffic safety performance of the school buses was discussed in details. It was found that school bus traffic accident rates were slightly increasing during the last five years. Yet, the fatality rates were decreasing though the past five years.

The "annual average rates" were used in comparing the UAE and other developed countries. The results indicated that the annual average fatality rates are little higher but close to the other countries' rates, while the annual average injury rates are much lower.

The overall users' (students) observation and opinion about evaluating the school bus service was "good". Students suggested few points related to providing training courses for the students, drivers and supervisors regarding the traffic safety of school buses. They also recommended improving the quality of seating and the provision of the seatbelts.

Throughout the study, the researchers were faced by several challenges to collect the data from the individual schools, particularly the private schools. As such, several recommendations aiming at improving the accuracy of the accident recording systems of the school buses and increasing the traffic safety awareness were reported. These recommendations are:

- Each school should utilize a unified database to record its own accidents. The database can be designed by the Police authorities in collaboration with traffic safety experts and the Ministry of Education;

- Each school should prepare an annual comprehensive study on performance of the school buses, and to be reviewed by the concerned stakeholders and authorities to take the necessary decisions, and provide solutions;

- Increase the traffic safety awareness related to the school buses (by providing lectures, booklets, and involving the role of media) to clarify and to discuss the traffic safety principles of school bus.

\section{ACKNOWLEDGMENT}

The authors are indebted to Abu Dhabi Education Council, the Ministry of Education in the UAE, and individuals, organizations and agencies for their help in completing this study.

\section{REFERENCES}

[1] Peter Daniels, "Stoke Newington Quakers - Early History." Part 1: to the mid-nineteenth century.

[2] School bus or alternative vehicle requirements, 2005. The Department of Transportation. Wisconsin, U.S.

[3] Traffic Safety Facts 2004, Department of Transportation, National Center for Statistics and Analysis, National Highway Traffic Safety Administration, , U.S., Washington, DC 20590, DOT HS 809919.

[4] Environmental Benefits, Fact: You can Go Green by Riding Yellow. American School Bus Council.

[5] J. Yang, C. Peek-Asa, G. Chengc,d, E. Heiden, S. Falb, and M. Ramirez, "Incidence and characteristics of school bus crashes and injuries," Accident Analysis and Prevention Journal, vol. 41, March 2009, pp. 336-341, doi:10.1016/j.aap.2008.12.012.

[6] Bus Industry Confederation, "Inquiry into National Road Safety," a submission to the House of Representatives Standing Committee on Transport and Regional Services into national road safety, October, 2003. MSA461.
[7] Transportation Research Board, "The Relative Risks of School Travel," Special Report 269, National Academy of Sciences, Washington, D.C, 2002. LB2864 .N336 2002, 371.8'72'0973—dc21.

[8] Land Transport Safety Authority, "School bus-related Safety- A literature review," 2002, ISBN 0-478-24135-6.

[9] Education Statistics First- 2010 Statistical Fact book Emirate of Abu Dhabi, Abu Dhabi Education Council, Abu Dhabi, United Arab Emirates, March 2010.

[10] Key Education Statistics for Dubai, Knowledge and Human Development Authority, Academic Year 2009/2010.

[11] J. Aldweiri. Ministry welcomes input on strategy, Al Khaleej news, Tuesday, 23 February 2010.

[12] The Survey System Calculator, Creative Research Systems.

[13] Traffic Safety Facts 2007. National Highway Traffic Safety Administration, National Center for Statistics and Analysis, U.S. Department of Transportation, Washington.

[14] Traffic Safety Facts 2006. National Highway Traffic Safety Administration, National Center for Statistics and Analysis, U.S. Department of Transportation, Washington.

[15] Traffic Safety Facts 2005. National Highway Traffic Safety Administration, National Center for Statistics and Analysis, U.S. Department of Transportation, Washington.

[16] Traffic Safety Facts 2004. National Highway Traffic Safety Administration, National Center for Statistics and Analysis, U.S. Department of Transportation, Washington.

[17] Traffic Safety Facts 2003. National Highway Traffic Safety Administration, National Center for Statistics and Analysis, U.S. Department of Transportation, Washington.

[18] Traffic Safety Facts 2002. National Highway Traffic Safety Administration, National Center for Statistics and Analysis, U.S. Department of Transportation, Washington.

[19] School Bus Collisions 1995-2004, December 2007. Road Safety and Motor Vehicle Regulation. Transport Canada, Canada.

[20] R. Brockington, "Summary Public School Indicators for the Provinces and Territories, 2000/2001 to 2006/2007". Culture, Tourism and the Centre for Education Statistics. Canada Statistics, Ottawa, Canada. 2009.

[21] C. Wilhelmson, July 2005, "Diesel School Bus Retrofit Pilot", Canada.

[22] School Transportation in Canada. School transportation news.

Nada B. Al Naser was born in 1984. She received the B.Sc. degree in Civil Engineering from United Arab Emirates University in 2007. She is now a M.Sc student in Civil Engineering program in UAE University. She is currently working as a research assistant, in the field of traffic and transportation engineering research, in the Roadway Transportation and Traffic Safety Research Center (RTTSRC) at UAE University. She was contributed in working on different number of TIS projects as well as Traffic Safety related Studies. Her main role in these projects is; Senior Traffic Engineer, Senior Traffic Safety Engineer, and Traffic Safety Data Analyst. Her research interests include traffic safety, traffic modeling and simulation addressed to identify the problems of the network, and traffic safety situation. Her research on these and other topics has appeared in different international conferences like; the International Conference on Road Safety in Four Continents (RS4C), the International Conference on Traffic and Transportation Engineering (ICTTE), and finally the 4th European Transport Research Arena (TRA 2012), at which a submitted paper has been accepted for presentation and publish.

Prof. Yaser E. Hawas currently serves as a professor at the Department of Civil and Environmental Engineering at the UAE University. He also serves as the Director of the RTTSRC at the UAE University. He obtained his Ph.D. from the Civil Engineering Department at the University of Texas at Austin in 1996, and joined UAE University in 1998. Dr. Hawas has published more than 40 international journal and conference papers. He has carried out several professional studies and consultancy works for local and international agencies including the Texas Department of Transportation (US), the Federal Highway Administration (US), Holden vehicle manufacturers (Australia), and the United Nations (ESCWA) among many others in the UAE. 